\title{
Car insurance in the age of self-driving - analysis of the Automated and Electric Vehicles Act 2018
}

With the inevitable rise of autonomous vehicles, it is vital for legislators to create legal frameworks for situations previously non-existent. Automated and Electric Vehicles Act 2018 enacted in the UK is an attempt in adjusting currently existing third-party insurance framework to the needs of driverless vehicles. The article is an attempt in analysis of "Part 1, Automated vehicles: liability of insurers etc" of the Act, its relatively limited scope, and norms introduced to regulate the cases of accidents of vehicles driving themselves without human intervention, and possible consequences of unauthorised software modifications in regards to insurers liability.

Keywords: car insurance, self-driving, autonomous vehicles, United Kingdom

\section{Introduction}

The Artificial Intelligence concept has its roots in the research of the computer scientists of the 1950s. The term was coined by Dr John McCarthy [of Massachusetts Institute of Technology at the time) in 1956. In a very broad definition, artificial intelligence is an emulation of some of the processes of the mind in the digital environment.

The pioneers of the computer science clearly underestimated the complexity of the mind as an information processing system and the initial optimism for a fully digital mind (so-called general artificial intelligence) gave way to the current scepticism towards the idea. However, the area of expert systems (i.e. the narrow artificial intelligence) is progressing rapidly and slowly creeping into the everyday lives of people around the world from digital assistants in our phones to self-driving vehicles varying in size from the house vacuum cleaner to trucks and buses ${ }^{1}$.

1. https://businessinsider.com.pl/technologie/nowe-technologie/autonomiczny-autobus-w-gdansku/ghq6zvf - Polish - press information about autonomous bus tests in Gdańsk, the author's home city. For English language information on the project related to the press info visit: http://www.sohjoabaltic.eu/ (both accessed on 21-09-2019) 
In recent years, autonomous vehicles moved from the pop culture of the 1980s (KITT of the " Night Rider" series being the prime example ${ }^{2}$ ) to more mundane, not crime-fighting, and definitely less opinionated self-driving cars of the 2010s. It is worth noting that while various experiments where conducted on driverless cars since at least the 1920s, the truly autonomous vehicles that are supposed to partake in general road traffic are in testing only relatively recently. Fully autonomous vehicles may bring a transport revolution only comparable with the invention of the car itself, reducing the need for driver's attention to the minimum, and promising gains in vehicle safety and reduction in the number of accidents.

The following article will take a look at the United Kingdom's recent attempts at regulating the budding autonomous vehicles market as represented by the Automated and Electric Vehicles Act 2018 in the context of insurance and liability. It will also look at different categories of autonomous vehicles as seen by the Thatcham Institute and take a comparative look at similar regulations in Poland.

\section{What is a self-driving vehicle?}

The answer to the above question is not as simple as it seems at first glance. There are several levels of automation and most of the vehicles entering the market currently are automated in some way or the other. We may not think of parking assistance ${ }^{3}$ or cruise control $^{4}$ as automation of driving, but they are taking some weight off the driver in certain scenarios, i.e. automating some driving tasks ${ }^{5}$. There's a big difference between parking assistance and fully autonomous vehicles, therefore various automotive industry groups have created scales of automation. The most famous of those (and the most widely used] is the one created by the Society of Automotive Engineers $(\mathrm{SAE})^{6}$. It is a six-point scale where " 0 " means no automation at all and " 5 " means completely autonomous driving.

2. https://www.imdb.com/title/tt0083437/ - IMDB page for the "Knight Rider" series (accessed on 21-09-2019)

3. https://en.wikipedia.org/wiki/Automatic_parking - (accessed on 26-09-2019)

4. https://en.wikipedia.org/wiki/Cruise_control - (accessed on 26-09-2019)

5. Adaptive Cruise Control is considered a level 1 automation on the 6-point scale of the Society of Automotive Engineers, a US transport industry group.

6. Funded in 1905, SAE became an international society of engineers connected with transport (mostly aviation and automotive], hence the name. 
Figure 1 - SAE levels of automation of motorised vehicles - https://www.sae.org/news/2019/01/saeupdates-j3016-automated-driving-graphic [accessed 2019-09-26]

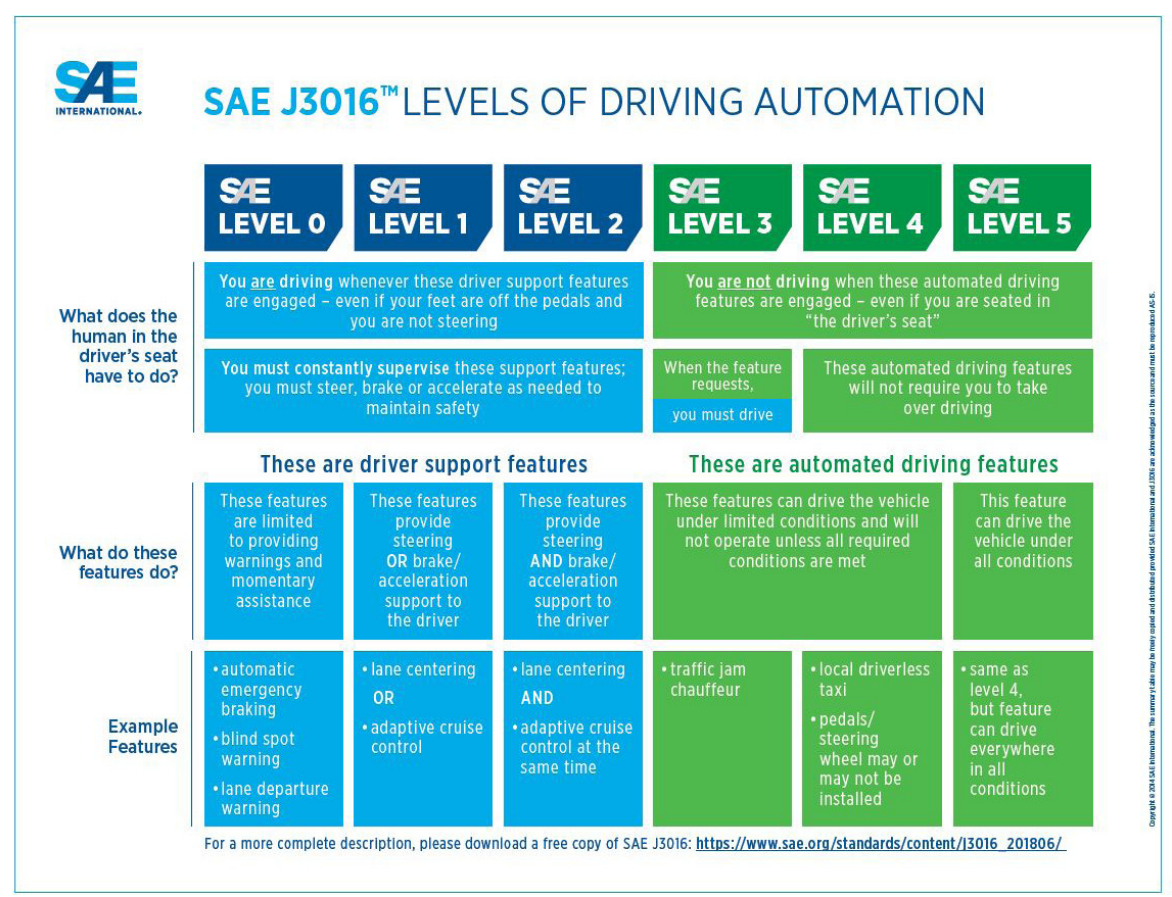

The same scale from 0 to 5 is used by Thatcham Research - the British insurer sponsored automotive research organisation, but the comments used by the British group below the pictures, which may have been planned as a humorous element, shows the general rule of autonomous vehicles - the higher the level, the less attention is needed on the part of user-in-charge.

Figure 2 Thatcham Research version of the SAE scale. "Defining Safe Automated Driving. Insurer Requirements for Highway Automation”, p. 18, 2019.

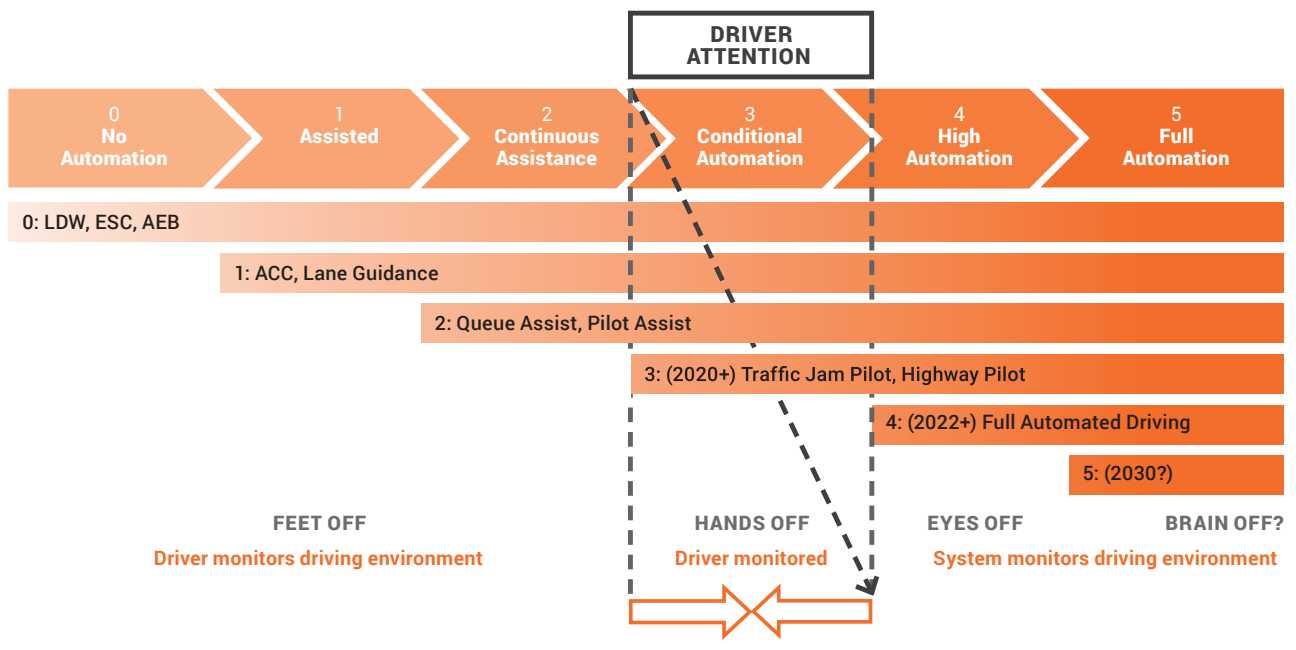


The currently commercially available vehicles are all in categories 0 and 1 (e.g. technologies like $A C C^{?}$ ], higher degrees of automation and fully autonomous vehicles are currently being researched by traditional automotive companies and other players not traditionally associated with car manufacturing like Alphabet-owned ${ }^{8}$ Waymo, although Thatcham Research concludes that it is unlikely that they will be widely available before the $2030 \mathrm{~s}^{9}$.

This varied landscape of technical developments is intertwined with the equally diversified regulatory environment. There are examples of relatively lax regulation like in some US states (e.g. California ${ }^{10}$ ) where it is permitted to use public roads for purposes of testing of autonomous vehicles provided that the fall-back of the remote operator is available and some additional administrative requirements are met. On the other hand, in Poland, where the testing of autonomous vehicles is regulated by articles $65 \mathrm{k}-65 \mathrm{n}$ of the Road Traffic Act of $1997,{ }^{11}$ it is stated that to get the necessary permit none of the owners of the real estate in the direct neighbourhood of the test route must object. The party responsible for the testing of autonomous vehicles must provide proof of insurance for the relevant vehicles. There is also a requirement for the back-up driver to be present at all times and for the testing of the vehicle to be restricted to the route specified in the permit issued by the authority responsible for the road in question. The fact that the party asking for permission does not have any recourse to the objection of real estate owners severely limits the ability to test self-driving and autonomous vehicles. While caution when testing new technology is laudable, the fact that this testing is so severely limited inhibits the development of relevant technologies and their prospective adoption, especially in the domain of public transport.

One of the more proactive examples of the government's regulation of the upcoming autonomous vehicle market is the Automated and Electric Vehicles Act $2018^{12}$ enacted in the United Kingdom of Great Britain and North Ireland. The act creates general rules regulating car insurance in the upcoming world of autonomous vehicles, and as such, it may be viewed as one of the blueprints that will be used by other countries.

7. Adaptive Cruise Control - the system where cruise control regulates speed in accordance to the situation on the road, whereas non-adaptive systems only maintain the pre-set speed and for any change need the driver's intervention.

8. Alphabet Inc - conglomerate company started by Google in 2015 owning various previously Google-owned ventures and Google itself.

9. Defining Safe Automated Driving. Insurer Guide for Highway Automation, Thatcham Research, September, 2019, available to download: https://www.thatcham.org/wp-content/uploads/2019/09/Defining-Safe-Automationtechnical-document-September-2019.pdf (accessed on 26-09-2019)

10. Official Department for Motorized Vehicles portal for self-driving regulations should be available at the following address: https://www.dmv.ca.gov/portal/dmv/detail/vr/autonomous/auto. Unfortunately, the web page for DMV did not work on several occasions, therefore the author had to rely on other sources, including the Wired Magazine article describing the regulatory proposal of 2018: https://www.wired.com/story/california-selfdriving-car-laws/ (Accessed on 26-09-2019)

11. Ustawa z dnia 20 czerwca 1997 r. Prawo o ruchu drogowym, Dz.U. $1997 \mathrm{nr} 98$ poz. 602 with all the subsequent amendments - official Polish text of the Act.

12. Automated and Electric Vehicles Act 2018, Available at: http://www.legislation.gov.uk/ukpga/2018/18/contents (Accessed 24-09-2019) 


\section{Overview of the Automated and Electric Vehicles Act 2018 and its enactment.}

The Act started its life as the Vehicle Technology and Aviation Bill ${ }^{13}$ in 2016 and contained regulations for automated and electric vehicles, civil aviation, and some additional amendments to existing laws. The bill fell because of the 2017 General Election but was reintroduced without the civil aviation regulations after the election and went through both houses of Parliament as the Automated and Electric Vehicles Bill ${ }^{14}$. After receiving the Royal Assent, the Bill became an Act of Parliament.

\subsection{The content of the Automated and Electric Vehicles Act $2018^{15}$.}

The Act contains three parts and a schedule of amendments to be made to existing laws. Part 1, which is the most relevant to this article and into which we will delve deeper in the next part of this article is entitled "Automated vehicles: Liability of insurers etc". It contains a rudimentary insurance framework for autonomous vehicles and charges the government with some additional tasks (e.g. maintaining the list of all self-driving vehicles that are allowed on the public roads of the United Kingdom).

Part 2, "Electric Vehicles: Charging", consists mainly of delegations of regulatory power on the executive branch of the government to create rules regarding the organisation of supply of energy for a growing number of electric vehicles. This part is not directly related to the topic of autonomous vehicles, but to the ongoing transformation of road transport from gasoline fuelled to electric. One notable part is in section 9, subsection (1) (b), that defines a "hydrogen refuelling point". In the opinion of the author, it is highly unlikely that these rules will have any practical implications, given the fact that any practical applications of hydrogen-based vehicles have failed to materialise. But the idea of "future-proofing" the legislation by anticipating the possible new adaptations and developments of the technology is highly laudable.

Part 3, "Miscellaneous and general", is rather self-explanatory. It consists of section 20, subsection (1), a provision to enact all the legislative changes that are in "The Schedule", creates a general delegation of power to the Secretary of State to issue regulations necessary for the fulfilment of the goals of the Act, and creates a collision rule for any amendments of legislation issued at the same or earlier session (section 20, subsection (4)]. Section 22 specifies the geographic extent of the Act, which is not typical in the relatively centralised and unitary country like Poland.

The Schedule lists all the changes in the existing legislation that are being made with the enactment of the Act.

13. https://services.parliament.uk/bills/2016-17/vehicletechnologyandaviation.html (accessed on 26-09-2019)

14. https://services.parliament.uk/bills/2017-19/automatedandelectricvehicles.html - UK Parliament's page for the Automated and Electric Vehicles Act 2018 - procedural information (accessed on 26-09-2019).

15. Automated and Electric Vehicles Act 2018, available at: $h$ ttp://www.legislation.gov.uk/ukpga/2018/18/contents (Accessed 26-09-2019). All further mentions of this Act are based on the most recent (with any amendments made since its enactment) version of the Act available at the time of writing. The Act's title will be shortened to AEVA. 


\subsection{Analysis of Part 1 of the Act and creating the framework for vehicle insurance for autonomous vehicles.}

The most interesting part of The Automated and Electric Vehicles Act 2018 is its first part, sections $1-8$. These sections create the basis for the development of an insurance system that is not driver-centric as in the current model, but vehicle-centric, which seems necessary in the world where a driver behind the wheel is not a given.

Section $1^{16}$ obliges the Secretary of State to create a list of all vehicles "capable, in at least some circumstances or situations, of safely driving themselves"1? and "may lawfully be used when driving themselves (...) in Great Britain". ${ }^{18}$ This section raises some questions regarding the definition of a self-driving vehicle (it seems somewhat broad, which may have been the legislators' objective. However, section 8, subsection (1)(a), practically narrows the definition to 4-5 on automation scales proposed by industry organisations. This section also creates a legal definition for use in this part of the Act for "automated vehicle" and defines it as listed in the above-mentioned register. So, for the purposes of Part 1 of the Act, an automated vehicle is one capable of "operating in a mode in which it is not being controlled, and does not need to be monitored, by an individual" ${ }^{19}$, hence automated to the degree of being capable of causing the accident in which driver/user in charge ${ }^{20}$ can be a party not responsible for causing the accident. An answer to that problem, from the insurance point of view at least, is codified in the following sections of the Act.

Section 2 creates general rules for liability in case of an accident both in a case when a vehicle is insured ${ }^{21}$ and uninsured ${ }^{22}$. In the case of an insured vehicle, when "an accident is caused by an automated vehicle when driving itself $(\ldots)^{23}$ and one of the persons involved (insured or otherwise) in an accident suffers damage as stated in subsection (1) (c), the insurer is liable. This is notable because it creates a situation when a user-in-charge can be a party suffering damage ${ }^{24}$ in the accident and covered by an insurance policy. Given the fact that it is mandatory to have at least a rudimentary car insurance when owning a vehicle, this will probably be the most widespread situation in the case of accidents involving self-driving vehicles.

16. All the quotes in part 3.2 of this article come from Automated and Electric Vehicles Act 2018, Available at: http://www.legislation.gov.uk/ukpga/2018/18/contents (Accessed 24-09-2019) - unless stated otherwise

17. Section 1(1)(a) AEVA

18. Section 1(1)(b) AEVA

19. Section 8(1)(a) AEVA

20. User-in-charge - term used by Thatcham Research and defined as: "When the ADS (automated driving system $-\mathrm{MM}$ ) is engaged, the User-in-Charge is the person who should be fit and ready to respond to an intervention request, whether planned or unplanned. A User-in-Charge will always be qualified and fit to drive the vehicle and will likely retain obligations in respect of, for example, vehicle roadworthiness and insurance." See: "Defining Safe Automated Driving", p. 6, Thatcham Research, 2019

21. Section 2(1) AEVA

22. Section 2(2) AEVA

23. Section 2(1) (a) AEVA

24. Damage is defined by section 2 (3), by "death or personal injury, and any damage to property other than ( ...)" the vehicle itself, goods transported by the vehicle, and "property in the custody, or under the control of" persons specified in point subsection (c) (i) and (c)(ii). 
In case of an uninsured vehicle driving itself causing an accident, when "a person suffers damage as a result of the accident" 25 and the vehicle is not "in the public service of the Crown"26 or not excluded from the requirement of having a third party insurance by section 144(2) of Road Traffic Act 198827, the owner of the vehicle is liable for that damage. Section 2(2) (c) practically limits the extent of this rule to privately owned vehicles, owners of which neglected to obtain the thirdparty insurance or more comprehensive coverage. This will definitely be a legal fall-back mechanism for those cases when, even though having in place at least a third-party insurance is mandatory in the UK, the owner of the vehicle fails to obtain insurance. As for the public service or vehicles in the service of the Crown, the rules shall be set separately from the AEVA.

Section 2(3) defines "damage" as used in Part 1 of the AEVA as "death or personal injury, and any damage to property other than "the automated vehicle"28,"goods carried for hire or reward in or on that vehicle or on any trailer (whether or not coupled) drawn by it"29 or "property in the custody, or under the control, of"30"the insured person"31, where section 2(1) AEVA applies (i.e. the vehicle is insured), or "the person in charge of the automated vehicle at the time of the accident"32, where section 2 (2) AEVA applies (i.e. the vehicle is not insured). In other words, section 2(3) AEVA creates a list of exceptions narrowing down the definition of damage. In practice, this will mean that a separate or more comprehensive insurance package would be needed to cover the vehicle itself, commercial transportation of goods [e.g. self-driving lorry transport], and other types of personal property carried on the vehicle. This is probably the most obvious example of a relatively limited scope of the AEVA - creating a rudimentary third-party insurance framework for driverless vehicles.

One can also find the link to existing car insurance regulations in the next subsection ${ }^{33}$. It limits the liability to the amount specified in section 154(4)(b) of the Road Traffic Act $1988^{34}$. Section $2(?)$ guarantees that "any other person's liability in respect of the accident" 35 will not be affected. Section 2(6) sets the semi-imperative character of the norm, as the only acceptable limitation of insurance coverage is a where modification of the software has been made by the insured person or the software has not been updated ${ }^{36}$. This is particularly important, as it signifies the software being the integral (and probably the most important) part of the car, part of the mechanism so to speak.

25. Section 2(2)(d) AEVA

26. Section 2(2)(c)(ii) AEVA

27. Road Traffic Act 1988, Section 144(2), Available at: http://www.legislation.gov.uk/ukpga/1988/52/section/144 (accessed: 29-09-2019] - the list of exceptions consists of mainly public service vehicle like Police, ambulances, fire units, etc.

28. Section 2(3)(a) AEVA

29. Section 2(3)(b) AEVA

30. Section 2(3) (c) AEVA

31. Section 2(3)(c) (i) AEVA

32. Section 2(3) (c) (ii) AEVA

33. Section 2(4) AEVA

34. At the time of writing that limit was set to $£ 1.200 .000$.

35. Section 2(?) AEVA

36. Section 2(6) AEVA 
The software modification provisions are in section $4^{37}$. It allows insurance policies to "exclude or limit the insurer's liability under section 2 (1)" if an accident occurred as a direct result of either "software alterations made by the insured person, or with the insured person's knowledge, that are prohibited under the policy" 38 or "a failure to install safety-critical software updates that the insured person knows, or ought reasonably to know, are safety-critical" ${ }^{39}$. The result of this section will be a massive adoption of clauses prohibiting any software alterations and penalising failure to update the software, which seems to be the result intended by the legislators - ratio legis for this section. The mandatory insurance will put market pressure on vehicle owners not to modify the software.

Another, highly unlikely but theoretically possible effect may be "a tinkerer's insurance" premium and probably highly expensive kind of insurance that allows the policy owner to modify the vehicle's driving software. These kind of policies would be a safe haven for users trying to modify their cars with custom software. In the light of the AEVA, this is permissible, however, there may be other laws issued that will ban the alterations outright or limit it otherwise. Due to the increasing complexity of motorised vehicles, in the author's opinion, the tendency both of the market (with terms of service and similar types of non-negotiable agreements) and the regulations will be to limit the ability of an owner of a vehicle to modify it as far as possible. This will be reflected in the development and availability of respective insurance products.

While owner-made modifications, "vehicle hacking", will probably never become too widespread, even if allowed at all, "failure to update" may have far more widely applicable consequences. Allowing the insurer to withdraw the insurance coverage, in that case, is meant to serve as an incentive for vehicle owners to keep their vehicles' controlling software properly updated. Every sufficiently complicated software system has some "unintended consequences" written into the algorithms, errors, or "bugs". In the case of a self-driving vehicle, the level of software changes being applied in the relatively short time will probably be enormous. Even more so, given the fact that the software systems controlling the vehicles will be based on artificial intelligence, which will be, to a degree, self-modifying systems, adjusting to new situations more on the principle of analogy, rather than the simple "if this then that". This kind of data will probably be also shared between vehicles in the form of software updates making the whole system safer and more reliable. This kind of telemetry is not within the scope of this article but raises a lot of interesting privacy-related concerns.

Software updates proliferation will probably be remedied more by the engineering and design solutions than legal ones. With default seamless updates, the mandatory network connection will probably make us unaware of the fact that the software is updated constantly in a similar way to modern web-browsers ${ }^{40}$. The question of whether opting out of the update process will be possible and legal at all remains open.

37. Section $4 \mathrm{AEVA}$

38. Section4(1) (a) AEVA

39. Section4(2) (a) AEVA

40. See: https://www.tesla.com/support/software-version-10-0\#software (access on 11-10-2019): "There is no need to request the update. You'll automatically receive Version 10.0 when it's ready for your car based on your location and vehicle configuration. Connect to Wi-Fi to ensure you can download and install." Please note, while the company used in the example (i.e. Tesla Motors) has not introduced any fully autonomous vehicles, they are researching the area intensively. They also made car software an important part of the vehicle, so in author's opinion similar notes will be a part of the experience of the autonomous vehicle owners. 
There are some additional rules and limitations to the abovementioned restrictions. The insured person who is not the holder of the policy is liable for the damages in case of an accident caused by software alterations ${ }^{41}$, only in the case of the "software alterations which, at the time of the accident, the person knows are prohibited under the policy." ${ }^{42}$ On the other hand, the amount paid by the insurer is recoverable "to the extent provided for by the policy" 43 from the person responsible (insured or otherwise ${ }^{44}$ ], if the accident is the result of software alterations prohibited by the polic ${ }^{45}$ or failing to apply a safety-critical update to the vehicle's software ${ }^{46}$. This right to recovery is limited in a similar fashion to section 4[2]: in the case of an insured person who is not a holder of the policy "subsection (4) (a) applies only in relation to software alterations which, at the time of the accident, the person knew were prohibited under the policy." ${ }^{2}$

Another factor limiting or excluding insurers' and owners' liability is contributory negligence. While an expectation of the user-in-charge dedicating her or his full attention to the road is not realistic, ${ }^{48}$ in the case of fully autonomous vehicles (level 4 and 5 ), in some cases we may still face the situation where there is a human factor involved. In cases when "an insurer or vehicle owner is liable under section 2 "49 to the injured party, but "the accident, or the damage resulting from it was to any extent caused by the injured party"50, the amount of the liability should be subject to reduction as prescribed by the Law Reform (Contributory Negligence) Act $1945^{51}$.

The liability of the owner or the insurer is excluded in respect of the person in charge of a selfdriving vehicle if the accident it caused "was wholly due to the person's negligence in allowing the vehicle to begin driving itself when it was not appropriate to do so" 52 . Therefore, in the light of the AEVA, there is still a vital role to be played by the user-in-charge of the vehicle and vehicles are not meant to be operated without any human supervision at all.

Sections 5-8 do not contain regulations that are specific to self-driving cars, rather more general norms regarding liability recovery, government obligations, and rules of interpretation. Section 5 regulates the liabilities and recovery between the insurer, owner, and the injured party, for example
41. Section 4(1) (a) AEVA
42. Section 4(2) AEVA
43. Section 4(4) AEVA
44. Section 4(3) AEVA
45. Section 4(4) (a) AEVA
46. Section 4(4)(b) AEVA
47. Section 4[5] AEVA

48. See: Jeffrey Gurney, SUE MY CAR NOT ME: PRODUCTS LIABILITY AND ACCIDENTS INVOLVING AUTONOMOUS VEHICLES, Journal of Technology Law \& Policy, ISSN 1087-6995, Vol. 2013. Accessed via: https://papers.ssrn. $\mathrm{com} / \mathrm{sol} /$ papers.cfm?abstract id=2352108 (Accessed on 2019-10-11) - the article contains the discussion of various possible models of liability and scenarios of driver/user-user-in-charge in regards to attention given to the road. The article points out that expecting the user-in-charge to pay the same level of attention to the road as in case of a regular driver is not only unrealistic, but defeats the purpose of introducing selfdriving vehicles. The author concurs.

49. Section 3(1) (a) AEVA

50. Section 3(1) (b) AEVA

51. Law Reform (Contributory Negligence) Act 1945, Available at: http://www.legislation.gov.uk/ukpga/Geo6/89/28/contents

52. Section 3(2) AEVA 
prohibiting recovery of more than the amount of the original liability ${ }^{53}$. Section 6 provides for a set of norms linking to other acts and regulations, setting the Act in the broader system of motor vehicle regulation in the United Kingdom with some region-specific links for Scotland being mentioned.

Section 7 obliges the Secretary of State to prepare a report for Parliament regarding the list of autonomous vehicles in the United Kingdom, and the efficacy of the law in regard to insurance matters and "other arrangements" ${ }^{154}$. The report should be provided within two years of the first publication of the self-driving vehicles' list. This self-review mechanism is interesting and has to be considered positively, given the fact that this kind of legislation is treading in untested waters and is trying to expand the mandatory insurance system to entirely new kinds of vehicles. In the new field of regulation, this kind of self-assessment of the laws is a tool that can be used to weed out the legislation's unintended negative consequences.

Section 8 contains a list of definitions and rules of interpretation to be used when applying the law.

\section{The meaning of the Automated and Electric Vehicles Act 2018 for automation of road transportation.}

The AEVA is not a major, sweeping, and truly ground-breaking piece of legislation. That is not necessarily a bad thing. The changes in road transportation due to the introduction of self-driving and autonomous vehicles will be gradual. That means that legislation that should regulate new vehicles should also be gradually added to the system of laws. Maybe in the future, those rules will have to be codified and put into one big act, but for the near-to-medium-term, both from the legislators' and citizens' point of view, incorporating into the system of laws smaller and more targeted types of legislation seems to be the way to go. We will probably witness many more amendments to the existing system of laws rather than anything resembling the "Self-Driving Vehicle Code". As different types of vehicles will co-exist on the public roads, so will the necessary regulations.

From the car insurance point of view, the AEVA clears up a lot of ambiguities and uncertainty around the introduction of autonomous vehicles onto the public roads. It creates rules for the situations where a car is in control and the user-in-charge is not the driver, and where the user-in-charge of the vehicle causing the accident may also be an injured party. It indirectly answers the question about the necessary level of due diligence that the user-in-charge of the vehicle is supposed to show while in the vehicle. The user-in-charge is responsible (and potentially liable) only for the misuse of self-driving, but is not expected to give the vehicle the same level of attention when in automatic mode, as in the manual control mode. This, in the author's opinion, should be regarded as a positive development, as it is completely unrealistic to expect the user-in-charge to be fully attentive all the time during the ride. Putting too much of a burden on the user-in-charge of a self-driving vehicle defeats the whole purpose of self-driving vehicles, especially in the scenarios when the vehicle is rented not owned. The user-in-charge would probably be willing to use his or her time spent in the vehicle for other tasks and may get distracted. Working on the assumption of the technology being sufficiently advanced to allow true self-driving, the scenario of a vehicle being "responsible" for causing an accident is highly likely.

53. Section 5(4) AEVA

54. Section ? (1) (b) AEVA 
What of the UK? Great Britain is trying to create an environment for high-tech and especially modern transportation infrastructure investment in the post-Brexit world. Laws like the AEVA are supposed to create legal certainty in new areas of industrial development. This kind of regulation should be commended. The United Kingdom is not willing to repeat the history of the so-called "Red Flags" Act where severe limits were imposed on the developing motorised transportation business ${ }^{55}$.

British legislators are trying to be a step ahead of the progress of technology. Usually, it is a case of the law not being up to speed with technological development. This is another commendable fact about this legislation, however there will definitely be a need to fix any holes in the current legislation. This makes the abovementioned self-review after two years ${ }^{56}$ a very interesting mechanism of adjusting the law to the needs of reality. Although, given the fact that it is a one-time review, in the author's opinion this is a wasted opportunity by the legislators of having a review of how the law is working in practice on a more regular basis. This means that amendments to AEVA will probably be added more reactively after the initial review is done and amendments there proposed. AEVA is a very general law, and even given all the self-correcting mechanisms built in, there will definitely be situations of interpretational ambiguity. This is a trap of proactive regulation: the legislator has to foresee what technology of the future will do to our lives and behaviour. And it is as often wrong as right. ${ }^{5 ?}$

For the transport insurance market, this Act means expanding the system to autonomous vehicles. Any kind of business likes certainty, and in case of car insurance, both drivers (or, in this case, users-in-charge) and insurance companies prefer to operate in a stable environment. This Act provides some stability to a very new piece of technology and automotive business. Will it serve its purpose of making the United Kingdom the hub for autonomous vehicles? When taken alone, definitely not, but it is a step in the direction of technological progress. This itself should be considered positive and probably be emulated in other countries. The Automated and Electric Vehicles Act 2018 is an example of a law that is designed for the future, created to avoid a regulatory void when self-driving cars finally become a part of the traffic landscape.

As research on autonomous vehicles progresses, this kind of regulation will be increasingly needed. The pace of development makes it hard for regulators and legislators to create the rules that would make most sense in the long run. Technology changes and evolves. We do not know what the final shape of the autonomous vehicle inhabited world will be. Car insurance is probably not the most glamorous part of the technological revolution, but even driverless cars will need third-party insurance.

55. The Locomotive Act 1865 obliged user of the public road to put a person with a red flag before the vehicle, that was travelling at the speed of $2 \mathrm{mph}$ (about $3 \mathrm{~km} / \mathrm{h}$ ). Those restrictions were abolished in 1896 and are often regarded as limiting factors in the development of the British automotive industry.

56. Section $?$ AEVA

57. For further discussion of proactive regulation problems in case of AEVA please refer to: Channon, M. Automated and Electric Vehicles Act 2018: An Evaluation in light of Proactive Law and Regulatory Disconnect, European Journal of Law and Technology (open access), vol 10, issue 2, 2019. 


\section{Bibliography}

Gurney J, Sue My Car Not Me: Products Liability And Accidents Involving Autonomous Vehicles, Journal of Technology Law \& Policy, ISSN 1087-6995, Vol. 2013.

Channon, M. Automated and Electric Vehicles Act 2018: An Evaluation in light of Proactive Law and Regulatory Disconnect, European Journal of Law and Technology (open access), vol 10, issue 2, 2019.

Defining Safe Automated Driving. Insurer Guide for Highway Automation, Thatcham Research, September, 2019

Autobus bez kierowcy już jeździ w Gdańsku. To pierwszy taki test w Polsce (Polish), https://businessinsider.com.pl/technologie/nowe-technologie/autonomiczny-autobus-w-gdansku/ghq6zvf - (accessed on 21-09-2019)

Wikipedia Article on Automatic Parking, https://en.wikipedia.org/wiki/Automatic_parking - (accessed on 26-09-2019]

Wikipedia Article on Cruise Control, https://en.wikipedia.org/wiki/Cruise_control - (accessed on 26-09-2019)

California Department for Moror Vehicles, Driverless Testing of Autonomous Vehicles: https://www. dmv.ca.gov/portal/dmv/detail/vr/autonomous/auto - (accesed on 21-11-2019)

Wired Magazine, Fully Self-Driving Cars Are Really Truly Coming to California: https://www.wired. com/story/california-self-driving-car-laws/ - (accessed on 26-09-2019)

Sohjoa Baltic Project, http://www.sohjoabaltic.eu/ - (accessed on 21-09-2019)

Discover Software Version 10.0, (press release), https://www.tesla.com/support/software-version10-0\# software (accessed on 11-10-2019)

\section{Ubezpieczenie odpowiedzialności cywilnej w dobie pojazdów autonomicznych - analiza brytyjskiej ustawy o pojazdach autonomicznych oraz elektrycznych}

W artykule dokonano analizy Automated and Electric Vehicles Act 2018, brytyjskiej ustawy majqcej na celu dopasowanie regulacji ubezpieczeń pojazdów mechanicznych do potrzeb ruchu drogowego, w którym będq uczestniczyły pojazdy autonomiczne i elektryczne. Autor skupia się na rozdziale pierwszym, poświęconym regulacji ubezpieczenia odpowiedzialności cywilnej w odniesieniu do pojazdów autonomicznych. Opisywane rozwiqzania prawne stanowiq wyraz dostosowania oraz dopasowania norm prawnych do sytuacji, w których pojazd posiada „użytkownika kontrolujacego” (user-incharge), zamiast kierowcy. Ponadto przepisy przewiduja konsekwencje nieuprawnionej modyfikacji oprogramowania na odpowiedzialność ubezpieczyciela.

Słowa kluczowe: ubezpieczenie pojazdu, pojazd autonomiczny, Wielka Brytania

MICHAŁ MARYNOWSKI - Phd student, University of Gdańsk 